\title{
Undergraduate nursing textbook coverage of menopause
}

\author{
Jennifer J. Markowitz ${ }^{1}$, J anet S Carpenter ${ }^{2}$ \\ 1. Indiana University, United States. 2. Center for Enhancing Quality of Life, Indiana University, United \\ States
}

Correspondence: Janet S. Carpenter. Address 1111 Middle Drive NU345, Indianapolis, IN 46202. Telephone: 317-278-6093. E-mail: carpentj@iupui.edu

Received: November 2, 2011

Accepted: December 7, $2011 \quad$ Published: May 1, 2012

DOI : $10.5430 /$ jnep.v2n2p18

URL: http://dx.doi.org/10.5430/jnep.v2n2p18

\section{Abstract}

Background: Menopause is a significant part of a woman's life, it would be expected that nursing students would learn a considerable amount about the changes women go through during this time. The study purpose was to assess the amount of information regarding menopause covered in undergraduate nursing textbooks.

Methods: 128 electronic undergraduate nursing textbooks from one publisher were evaluated for menopause content in 11 areas and categorized as having no information (0), some information (1), or complete information (2). The word menopause was searched for each textbook.

Results: The number of search hits for the word menopause per textbook was most commonly 1 , with $50 \%$ having fewer than 7 search hits, and an overall average of 14.02 hits per textbook ( $S D=15.15$, range 1 to 60 ). The majority of textbooks had no or minimal information about menopause in each category.

Conclusions: There is minimal information on menopause in undergraduate nursing textbooks. This suggests that undergraduate nursing students may not be receiving the necessary information to adequately care for menopausal women.

\section{Key words}

Menopause, Education, Nursing, Baccalaureate, Health education, Women’s health, Trends

\section{Introduction}

Every woman will reach menopause if she lives long enough. Menopause is defined as the "final menstrual period" and “... is recognized to have occurred after 12 months of amenorrhea with no obvious pathologic cause” ${ }^{[1]}$. The average age that menopause occurs naturally is approximately 51 years of age ${ }^{[1]}$. Signs and symptoms of menopause include but are not limited to uterine changes, vasomotor symptoms such as hot flashes, sleep disturbances, headaches, depressed mood, vaginal changes, changes in sexual function, urinary incontinence, weight gain, changes in breast tissue, and changes in the skeletal and cardiovascular system. These signs and symptoms add complexity to other acute and chronic health care conditions. For example, estrogen deficiency is related to bone loss from the spine which adds to complications of osteoporosis ${ }^{[1]}$. Understanding the complexities of menopause will be relevant to a variety of nurses working with women 
that have reached this time point in their lives. However, the amount of content that undergraduate nursing students are exposed to related to menopause is not clear.

The terms "textbook and menopause", "book and menopause" and "nursing textbook coverage" were entered into OVID and PubMed search engines on April 10, 2009 and August 30, 2010. Only two articles were located - one related to disability content ${ }^{[2]}$ and one related to family violence ${ }^{[3]}$. No article was found that evaluated any textbook for menopause content.

Other articles were found by clicking on the links for suggested articles in the electronic search engines. One article was found related to a study of end-of-life content in nursing textbooks in OVID ${ }^{[4]}$. Because the methods used in the end- oflife study were relevant to this project, additional similar articles covering other content areas were located. The additional articles evaluated nursing and medical textbooks. Articles evaluated coverage of symptom assessment and management in nursing textbooks ${ }^{[5]}$, end-of-life content in critical care nursing textbooks ${ }^{[6]}$, the role of oncology nursing to ensure quality care for cancer survivors ${ }^{[7]}$, palliative care content in nursing textbooks ${ }^{[8]}$, pain content in nursing textbooks ${ }^{[9]}$, and death and bereavement in nursing ${ }^{[10]}$, medical textbooks ${ }^{[11]}$, and geriatric textbooks ${ }^{[12]}$. Two other articles were reviewed on medical textbook coverage of fluid management in post-surgical patients ${ }^{[13]}$ and sleep medicine ${ }^{[14]}$. In general, the articles concluded that these topics were not well covered in textbooks, suggesting potential gaps in student learning. In a similar fashion, if nursing undergraduate textbooks do not cover menopause content, there may be potential for a gap to occur in student learning.

The purpose of this study was to describe menopause content in undergraduate nursing textbooks.

\section{Methods}

This was a cross-sectional descriptive study. Undergraduate nursing textbooks were the sample studied.

Methods for this study were similar to methods used in the articles identified above through our search process. The research team consisted of an undergraduate nursing honors student and a faculty member. The research team contacted the school's nursing textbook publishing representative. After explaining the purpose of the study to the representative, the team was provided a website with information on how to log in and asses the e-books textbooks for one publisher online. Both research team members created a username and password but the faculty portion provided greater access to the needed information, allowing the team to select undergraduate nursing textbooks, the area of focus for this project. Upon entering into the publisher's e-books site, "menopause" was entered into the search box, which generated a list of references that contained the term menopause. References included 128 books as well as 7 audio recordings. The audio recordings were not included in this project because they were not technically textbooks. For each textbook, the number of hits was provided - this was the number of times the term menopause appeared within the book content. A complete list of the 128 textbooks is available from the authors.

The research team created a list of criteria related to menopause that the research team hoped to find in each of the online undergraduate nursing textbooks. These criteria were selected based on expertise of the faculty member, after reviewing Menopause Practice: A Clinician's Guide, 4th edition ${ }^{[1]}$ and searching tables of contents from other books related to menopause. The most commonly covered topics were selected to use as criteria each textbook should include. The following criteria were selected:

- Definitions of early and late perimenopause, early and late postmenopause, menopause; the Stages of Reproductive Aging Workshop (STRAW) ${ }^{[15]}$ menopause categories;

- Average age;

- Physiological changes; 
- Common clinical issues;

- Disease risk (including bone, heart, breast, uterine health);

- Clinical evaluation (how to diagnose, identify stage, evaluate symptoms);

- Hormonal therapies (doses, risks, benefits, side effects, duration of treatment);

- Non-hormonal prescription therapies (doses, risks, benefits, side effects, duration of treatment);

- Non-prescription / alternative therapies (type, amount / dose, risks, benefits, side effects, duration of treatment);

- Nutrition;

- Effects of exercise.

The research team created a review table listing the title of the book, number of search results, and each of the criteria (see Table 1). The research team assessed menopause content in each of the 128 books and each criterion was rated as having no information (0), some information (1), or complete information (2). The research team verified they were appropriately abstracting the information from the online textbooks onto the checklist. One team member verified a random selection of $10 \%$ of the other team member's results. Inter-rater reliability was $94 \%$ but all disagreements were related to one single textbook. That book was discussed and consensus was reached. Data were corrected to reflect the consensus agreement and the corrected data were used in the analysis.

Table 1. Literature Search Results Yielding Similar Articles Evaluating Textbook Coverage of Other Topics

\begin{tabular}{|c|c|c|c|c|}
\hline Author, Date & Topic & Discipline & \# Books reviewed & $\begin{array}{l}\text { Topic adequately } \\
\text { covered? }\end{array}$ \\
\hline Carron, Lynn, Keaney, 1999 & End-of-Life Care & Medicine & 4 & No \\
\hline Chawla, Drummond, 2008 & $\begin{array}{l}\text { Fluid management of } \\
\text { patients after surgery }\end{array}$ & Medicine & 22 & No \\
\hline Ferrell, Virani, Grant, 1999 & End-of-Life Content & Nursing & 50 & No \\
\hline Ferrell, Virani, Grant, 1999 & $\begin{array}{l}\text { Symptom Assessment } \\
\text { and Management } \\
\text { Content }\end{array}$ & Nursing & 50 & No \\
\hline $\begin{array}{l}\text { Ferrell, Virani, Grant, } \\
\text { Borneman, } 1999\end{array}$ & $\begin{array}{l}\text { Death and Bereavement } \\
\text { Content }\end{array}$ & Nursing & 50 & No \\
\hline $\begin{array}{l}\text { Ferrell, Virani, Grant, Juarez, } \\
2000\end{array}$ & Palliative Care Content & Nursing & 50 & No \\
\hline $\begin{array}{l}\text { Ferrell, Virani, Grant, } \\
\text { Vallerand, McCaffery, } 2000\end{array}$ & Pain Content & Nursing & 50 & No \\
\hline $\begin{array}{l}\text { Kirchoff, Beckstrand, } \\
\text { Anumandla, } 2003\end{array}$ & End-of-Life Content & Critical Care Nursing & 14 & No \\
\hline Parsons, Moore, 1998 & Family Violence & $\begin{array}{l}\text { Obstetrics, Gynecology, } \\
\text { Primary Care, and } \\
\text { Nursing }\end{array}$ & $\begin{array}{l}48 \text { medical \& } \\
19 \text { nursing }\end{array}$ & No \\
\hline $\begin{array}{l}\text { Smeltzer, Robinson-Smith, } \\
\text { Dolen, Duffin, Al-Maqbali, }\end{array}$ & $\begin{array}{l}\text { Disability-related } \\
\text { Content }\end{array}$ & Nursing & 33 & No \\
\hline $\begin{array}{l}\text { Teodorescu, Avidan, } \\
\text { Teodorescu, Harrington, } \\
\text { Artar, Davies, et al., } 2007\end{array}$ & Sleep Medicine Content & Medicine & 31 & No \\
\hline Wu, Malik, Higginson, 2006 & End of life content & Geriatric medicine & 5 & No \\
\hline
\end{tabular}


Predictive Analytics Soft Ware (PASW) statistics v.17 was used for analysis. Frequency distributions for each menopause content criteria were generated. This provided the percentages of textbooks having no, some, or complete information in each content area.

\section{Results}

The undergraduate nursing textbooks covered a broad range of topics such as medical-surgical nursing, women's health, gerontology, maternity, communication, nutrition, pathophysiology, and pharmacology. Of the 128 books assessed, the number of search hits per textbook was most commonly 1, with $50 \%$ having 7 or fewer search hits, and an overall average of 14.02 hits per textbook ( $S D=15.15$, range 1 to 60$)$.

Figure 1 shows the level of information in the textbooks. An overview of the findings for each menopause content criterion is listed below. The percentage of books that had no information included: a) 59\% did not contain definitions of early and late perimenopause, early and late postmenopause, menopause, or STRAW menopause categories; b) 61\% did not include average age at menopause; c) $48 \%$ no information on physiological changes; d) $52 \%$ no discussion of common clinical issues such as hot flashes, sleep disturbances, or other symptoms; e) $95 \%$ no clinical evaluation; f) 53\% no hormonal therapies; g) 91\% no non-hormonal prescription therapies; h) 72\% no nonprescription / alternative treatments; i) $75 \%$ no nutrition; and j) 84\% no discussion of effects of exercise. In contrast, $61 \%$ did contain some information on disease risk (e.g., heart, bone, breast, uterine health). No textbooks had complete information in the categories of clinical evaluation, non-hormonal prescription and non-prescription / alternative therapies. Complete information in any category was missing from over $90 \%$ of textbooks.

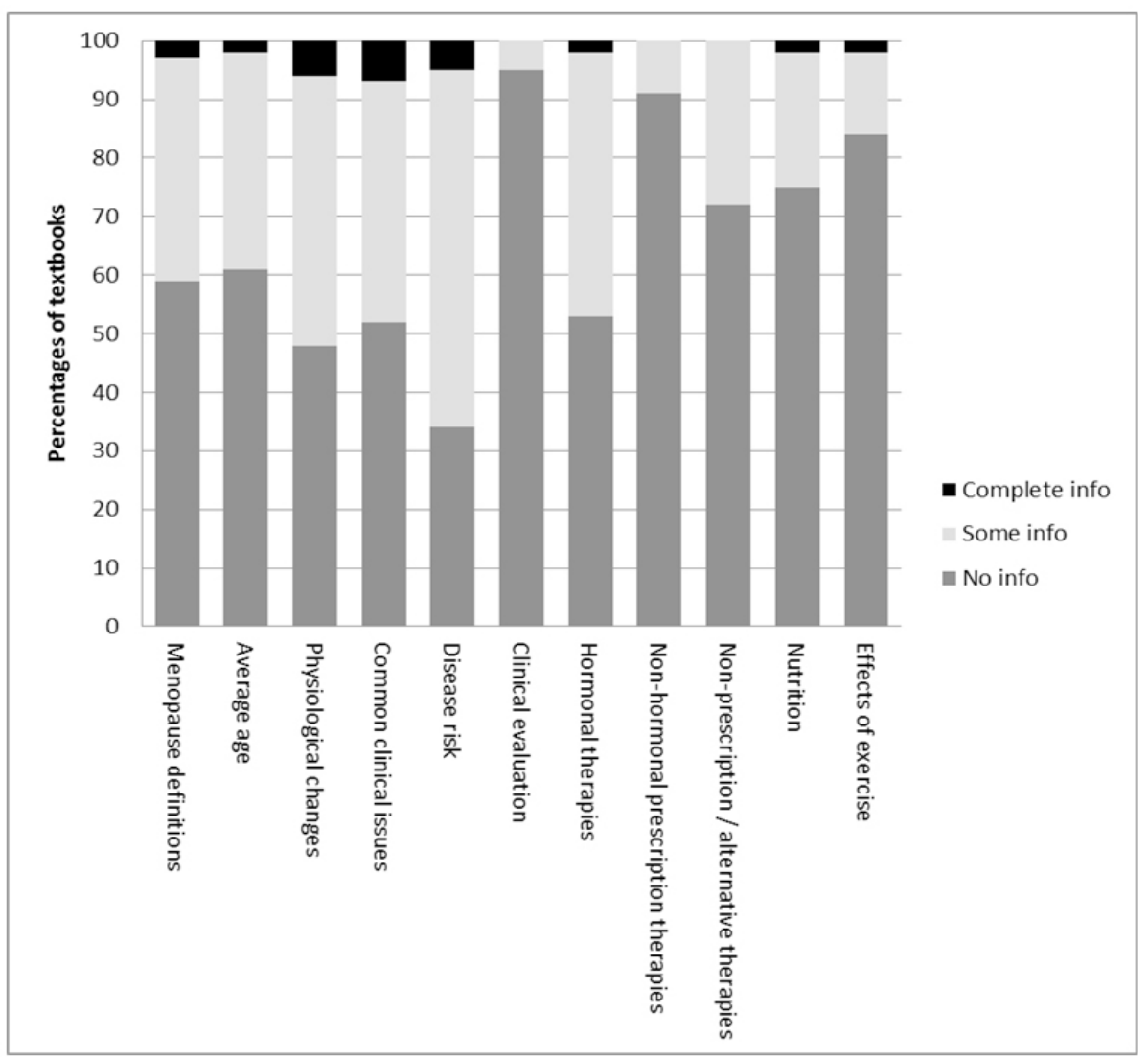

Figure 1. Percentages of Textbooks with Complete, Some, or No Information in Each Menopause-related Content Area 


\section{Discussion}

This project demonstrates that there is an insufficient amount of content regarding menopause in undergraduate nursing textbooks. The minimal content found in textbooks is the only access to menopause content that students are receiving in the classroom, unless the professor is including additional didactic content, handouts, or readings.

This lack of information that undergraduate nursing students are receiving can create gaps in bedside nursing care. For example, a hospitalized patient in her 50s may be having difficulty with hot flashes, a headache, and difficulty sleeping. She may be transitioning through menopause, yet these symptoms could be confused as a new illness. Since information regarding menopause may not be covered thoroughly in undergraduate classes, the staff nurse may not know how to properly assess and evaluate menopausal patients. Therefore, the patient may not get the proper treatment or education for the signs and symptoms she is experiencing.

There were some limitations for this study. Only undergraduate nursing textbooks from one publishing company were reviewed. Additional materials that might have been used for teaching menopause content were not assessed (e.g., slides, pamphlets, websites). The areas selected were assumed to be the most significant to menopause education. This review did not assess content in medical textbooks or graduate nursing books. The list of textbooks was generated at a single point in time and the publisher may have added more information since that time.

Additional material should be considered for inclusion in undergraduate nursing education to supplement the information provided in textbooks. A reliable source includes Menopause Practice: A clinician's guide, 4th edition developed by the North American Menopause Society Professional Education Committee ${ }^{[1]}$.

\section{References}

[1] North American Menopause Society. Menopause practice: A clinician's guide, 4th edition. Mayfield Heights: North American Menopause Society. 2010.

[2] Smeltzer SC, Robinson-Smith G, Dolen MA, Duffin JM, Al-Maqbali M. Disability-related content in nursing textbooks. Nurs Educ Perspect. 2010; 31: 148-155. PMid:20635618

[3] Parsons LH, Moore ML. Family violence issues in obstetrics and gynecology, primary care, and nursing texts. J Obstet Gynecol. 1998; 91:158-159.

[4] Ferrell B, Virani R, Grant M. Analysis of end-of-life content in nursing textbooks. Oncol Nurs Forum. 1999; 26: 869-876. PMid:10382185

[5] Ferrell BR, Virani R, Grant M. Analysis of symptom assessment and management of content in nursing textbooks. J Palliat Med. 1999; 2: 161-172. PMid:15859813 http://dx.doi.org/10.1089/jpm.1999.2.161

[6] Kirchoff KT, Beckstrand RL, Anumandla PR. Analysis of end-of-life content in critical care nursing textbooks. J Profess Nurs. 2003; 19: 372-381. http://dx.doi.org/10.1016/S8755-7223(03)00141-8

[7] Ferrell BR, Virani R, Smith S, Juarez G. The role of oncology nursing to ensure quality care for cancer survivors: a report commissioned by the National Cancer Policy Board and Institute of Medicine. Oncol Nurs Forum. 2003; 30:E1-E11. PMid:12515992 http://dx.doi.org/10.1188/03.ONF.E1-E11

[8] Ferrell B, Virani R, Grant M, Juarez G. Analysis of palliative care content in nursing textbooks. J Palliat Care. 2000 ; 16 : 39-47.

[9] Ferrell B, Virani R, Grant M, Vallerand A, McCaffery M. Analysis of pain content in nursing textbooks. J Pain Symptom Manage. 2000; 19: 216-228. http://dx.doi.org/10.1016/S0885-3924(00)00107-X

[10] Ferrell B, Virani R, Grant M, Borneman T. Analysis of content regarding death and bereavement in nursing texts. Psycho-oncol. 1999; 8:500-510. http://dx.doi.org/10.1002/(SICI)1099-1611(199911/12)8:6<500::AID-PON411>3.0.CO;2-8

[11] Carron AT, Lynn J, Keaney P. End-of-life care in medical textbooks. Ann Intern Med. 1999; 130:82-86. PMid:9890873

[12] Wu H, Malik F, Higginson I. End of life content in geriatric textbooks: what is the current situation? BMC Palliat Care. 2006 ; 5: 5. PMid:16737524 http://dx.doi.org/10.1186/1472-684X-5-5 
[13] Chawla G, Drummond GB. Textbook coverage of a common topic: fluid management of patients after surgery. Med Educ. 2008; 42: 613-618. PMid:18435711 http://dx.doi.org/10.1111/j.1365-2923.2008.03009.x

[14] Teodorescu MC, Avidan AY, Teodorescu M, Harrington JJ, Artar AO, Davies CR. et al. Sleep medicine content of major medical textbooks continues to be underrepresented. Sleep Med. 2007; 8: 271-276. PMid:17369089 http://dx.doi.org/10.1016/j.sleep.2006.09.001

[15] Soules MR, Sherman S, Parrott E, Rebar R, Santoro N, Utian W, Woods N. Executive summary: Stages of Reproductive Aging Workshop (STRAW) Park City, Utah, July, 2001. Menopause. 2001; 8: 402-407. PMid:21141649 http://dx.doi.org/10.1097/00042192-200111000-00004 